\title{
APPBP2 wt Allele
}

National Cancer Institute

\section{Source}

National Cancer Institute. APPBP2 wt Allele. NCI Thesaurus. Code C52277.

Human APPBP2 wild-type allele is located within 17q21-q23 and is approximately $83 \mathrm{~kb}$ in length. This allele, which encodes amyloid protein-binding protein 2 , is involved in the regulation of protein transport and processing. This gene has multiple polyadenylation sites and has been found to be highly expressed in breast cancer. 